\title{
Amerykanki i kwestia kobieca na łamach „Tygodnika Mód i Powieści” w latach 1860-1915
}

\section{Streszczenie}

W poniższym artykule skupię się na tym, jak w „Tygodniku Mód i Powieści" przedstawiano Amerykanki i ich walkę o równouprawnienie. Przeanalizuję artykuły zamieszczone w nim w latach 1860-1915, czyli od przejęcia pisma przez Jana Kantego Gregorowicza do końca jego istnienia. W drugiej połowie XIX w. prasa coraz częściej pisała o kobietach i sprawach im bliskich. Miało to niewatpliwie zwiazek ze wzrostem ich aktywności i rozwojem ruchu emancypacyjnego. Amerykanki odegrały pod tym względem niebagatelną rolę, walcząc o przyznanie im praw w różnych sferach życia. Kwestia równouprawnienia była aktualna również na ziemiach polskich. Ówcześni publicyści dostrzegali potrzebę edukacji kobiet, a szczególnie praktycznego ich kształcenia oraz konieczność podjęcia przez nie pracy zawodowej. W „Tygodniku Mód i Powieści” zamieszczono wybiórcze informacje o: rozwoju ruchu kobiecego w USA, walce Amerykanek o przyznanie im praw politycznych, edukacji kobiet, podejmowaniu przez nie pracy w zawodach zarezerwowanych wcześniej dla mężczyzn oraz zaangażowaniu w tworzenie klubów kobiecych. Wiele amerykańskich inicjatyw nie spotkało się $z$ aprobatą redaktorów tygodnika. Wielokrotnie postulowali oni o nieprzenoszenie ich na grunt polski, chociaż dostrzegano potrzebę zmian i ustępstw w niektórych dziedzinach życia. 
Słowa kluczowe: kobiety, Amerykanki, prasa warszawska, „Tygodnik Mód i Powieści”, ruch kobiecy, prawa kobiet, prasa kobieca, Stany Zjednoczone, Ameryka, społeczeństwo amerykańskie

\title{
AMERICAN WOMEN AND WOMEN'S ISSUE IN “TYGODNIK MÓD I POWIEŚCI” IN 1860-1915
}

\begin{abstract}
In the article, I will focus on the question how American women and their struggle for gender equality were presented in "Tygodnik Mód i Powieści" ["Weekly of Fashion and Novels"]. I will analyse articles posted to the magazine in the years 1860-1915, i.e. since its takeover by Gregorowicz until the end of its existence. In the second half of the 19th century, the press more and more frequently wrote about women and the issues concerning them. This was undoubtedly related to the increase in women's activity and the development of the emancipation movement. American women, fighting for their rights in various spheres of life, played a significant role in this respect. The issue of gender equality was also valid in Poland. Contemporary publicists noticed the need of women's education, especially - practical education and the necessity of taking up professional work by women. “Tygodnik Mód i Powieści” selectively informed about: the development of women's movement in the USA, American women's fight for political rights, women's education, taking up jobs in professions previously reserved for men and involvement in creating women's clubs. Many American initiatives were not approved by the weekly's editors, who insisted that they should not be transferred to Poland. Yet, the need for changes and concessions in some areas of life was recognized.
\end{abstract}

Keywords: women, American women, Warsaw press, women's movement, women's press, women's rights, United States, America, American society

\section{Wprowadzenie}

W drugiej połowie XIX w. prasa coraz częściej pisała o kobietach i sprawach im bliskich. Miało to niewatpliwie zwiazek ze wzrostem ich aktywności i rozwojem ruchu emancypacyjnego. Amerykanki odegrały pod tym względem niebagatelną rolę, walcząc o przyznanie im praw w różnych sferach życia. Kwestia równouprawnienia była aktualna rów- 
nież na ziemiach polskich. Ówcześni publicyści dostrzegali potrzebę edukacji kobiet, a szczególnie praktycznego ich kształcenia. Apelowano o to, ponieważ wyższe kwalifikacje zawodowe pomogłyby im odnaleźć się na rynku pracy. Warto podkreślić, że nie zawsze mogły one liczyć na wsparcie finansowe ze strony mężów czy ojców. Ponadto nieraz musiały wspomagać budżet domowy, gdyż dochody mężczyzny bywały niewystarczajace, by utrzymać rodzinę. Inną kwestia, na która próbowano zwrócić uwagę, była konieczność dopuszczenia ich do profesji zarezerwowanych wcześniej dla mężczyzn, a przynajmniej zwiększenia liczby wykonywanych przez nie zawodów. Budziło to wiele kontrowersji i wymagało podjęcia długotrwałej walki. Na ziemiach polskich aspiracje polityczne kobiet nie miały jeszcze racji bytu, chociaż bacznie przyglądano się ich staraniom w innych krajach.

Zainteresowanie kobietami i ich problemami, a także ich coraz większa aktywność wpływały na dynamiczny rozwój prasy kobiecej. Należy zaznaczyć, że tematyka ta przewijała się w większości ówczesnych pism, choć w tym typie, $z$ wiadomych względów, musiała być bardziej wyeksponowana. W drugiej połowie XIX stulecia w zaborze rosyjskim wiodacca rolę odgrywały dwa tytuły: „Bluszcz” oraz „Tygodnik Mód i Powieści”. Oba cieszyły się niesłabnąca popularnościa, dlatego przetrwały na rynku wydawniczym Warszawy kilkadziesiąt lat. „Tygodnik Mód i Powieści" był jak dotąd mniej wykorzystywanym źródłem, choć można znaleźć w nim wiele cennych informacji o ówczesnej sytuacji kobiet na ziemiach polskich, a także w różnych zakątkach świata. Ponadto kierowano go do innego typu odbiorcy, mniej wymagającego.

Poczatki „Tygodnika Mód i Powieści” sięgaja 1835 r., kiedy to Jan Glücksberg zaczął wydawać pismo o nazwie „Magazyn Mód czyli Dziennik Przyjemnych Wiadomości”. Wówczas skupiano się w nim głównie na kwestiach mody i obyczajów, mniejsze znaczenie miał dodatek powieściowy. Na uwage zasługiwała bogata szata graficzna, która jednakże wpływała na jego cenę. W 1860 r., po przejęciu przez Jana Kantego Gregorowicza, nastapiła zmiana nazwy na „Magazyn Mód i Nowości dotyczących gospodarstwa domowego”, a w 1862 r. na „Tygodnik Mód i Nowości Dotyczących Gospodarstwa Domowego". W tej formie periodyk przetrwał do 1871 r., kiedy zmieniono go na „Tygodnik Mód i Powieści”. W 1911 r. do tytułu głównego dodano podtytuł „Nasz Dom”. W kolejnym roku czasopismo funkcjonowało już jako „Nasz Dom”. W tej postaci przetrwało do 1915 r. Dalsze wydawanie uniemożliwiły działania zbrojne. Nie zostało 
ono, śladem „Bluszczu”, „Dobrej Gospodyni” czy „Ziemianki”, wznowione po wojnie ${ }^{1}$.

Po przejęciu pisma przez Jana Kantego Gregorowicza nastapił wzrost poczytności. Stało się tak dzięki urozmaiceniu treści, a nie ograniczaniu się, jak bywało wcześniej, do omawiania najnowszych trendów w modzie. Dowiódł on tym samym, że publikowanie materiałów poświęconych prawie wyłącznie strojom nie wystarczało, by przyciagnać uwagę czytelniczek. Wprawdzie nie brakowało w nim informacji $z$ tej dziedziny, ale oprócz nich pojawiły się teksty dotyczące obyczajów, kultury, historii, literatury, teatru oraz muzyki. Ważnym elementem każdego numeru były relacje $z$ podróży. Duża w tym zasługa Sygurda Wiśniowskiego, który przez kilka lat dostarczał zajmujących opisów swoich wędrówek. Gregorowicz dbał też, żeby publikowane materiały przedstawiano w sposób przystępny, by mogły je zrozumieć mniej wykształcone czytelniczki².

W „Tygodniku Mód i Powieści” zwracano szczególna uwage na watki bliskie kobietom. Autorzy dalecy byli jednak od jakichkolwiek deklaracji ideowych i skrajnych poglądów. Unikano podejmowania kwestii emancypacji, aby nikogo do siebie nie zrażać. Poruszano się raczej po mniej kontrowersyjnym gruncie. Czytelniczki próbowano zainteresować artykułami o charakterze informacyjnym, poradnikowym oraz literackim. Temat równouprawnienia ograniczono do kwestii pracy zarobkowej kobiet, utrzymania rodziny i wychowywania dzieci, chociaż zdawkowe wiadomości o aspiracjach politycznych również przemycano, $z$ tym że czyniono to na przykładzie chociażby Amerykanek. Warto podkreślić, iż w Stanach Zjednoczonych sprawa kobieca była o wiele dalej posunięta, w związku z tym rozwiązania tam stosowane mogły stanowić wzór i przykład dla Polek. Pod koniec XIX stulecia w tygodniku zaczęto propagować hasła antyfeministyczne, w ten sposób zrobiono krok w tył, ponieważ wcześniej program był bardziej postępowy ${ }^{3}$.

\footnotetext{
1 Zenon Kmiecik, „Prasa polska w Królestwie Polskim i Imperium Rosyjskim w latach 1865-1904”, w: Jerzy Łojek (red.), Prasa polska w latach 1864-1918, (Warszawa : PWN, 1976), 77; Idem, Prasa warszawska w latach 1886-1904, (Wrocław : Zakład Narodowy im. Ossolińskich, 1989), 139-142; Zofia Zaleska, Czasopisma kobiece $w$ Polsce (materiały do historii czasopism). Rok 1818-1937, (Warszawa : Wyższa Szkoła Dziennikarska, 1938), 235.

2 Zenon Kmiecik, Prasa warszawska w okresie pozytywizmu (1864-1885), (Warszawa : PWN, 1975), 131-132; Jerzy Franke, Polska prasa kobieca w latach 1820-1918: w kregu ofiary i poświęcenia, (Warszawa : Wydawnictwo SBP, 1999), 79-92.

3 Jerzy Franke, Polska prasa kobieca, 86-87, 211-216.
} 
Na początku XX w. „Tygodnik Mód i Powieści” był wiodącym pismem kobiecym. Pod względem liczby sprzedanych egzemplarzy przewyższał nawet „Bluszcz”. W 1912 r. jego jednorazowy nakład wynosił 12 tys. egz. Popularność swą zawdzięczał niskiej cenie oraz przystępnemu, różnorodnemu materiałowi publikowanemu na jego łamach. Zmiana charakteru pisma nastapiła po 1907 r., kiedy to do redakcji przyszła Lucyna Kotarbińska. Pełniła ona nawet nieoficjalnie rolę redaktora naczelnego. W tym czasie publikowano jeszcze więcej artykułów o charakterze poradnikowym, nie krytykowano emancypacji, ale popierano wyłącznie powolne zmiany ${ }^{4}$.

W poniższym artykule skupię się na tym, jak w „Tygodniku Mód i Powieści" przedstawiano Amerykanki i ich walkę o równouprawnienie. Przeanalizuję artykuły zamieszczone w latach 1860-1915, czyli od przejęcia pisma przez Gregorowicza do końca jego istnienia. Zbadam, na jakie aspekty ich aktywności zwracano szczególną uwagę, a które pomijano. Warto odpowiedzieć na pytanie, czy w ciągu kilkudziesięciu lat zmieniło się ich postrzeganie i jak je oceniano.

\section{Emancypacja}

W „Tygodniku Mód i Powieści” podejmowano różne kwestie zwiazane $z$ Amerykankami. Pisano o ich wychowaniu, życiu rodzinnym, edukacji, pracy zarobkowej, a także o działalności na różnych płaszczyznach życia. Jednym $z$ problemów poruszanych na łamach omawianego czasopisma była ich walka o przyznanie praw. Często pisano o tym $z$ pewna dozą ironii, nieraz traktowano to jako swoistą ciekawostkę czy fanaberię.

Pierwszy artykuł o emancypacji ${ }^{5} \mathrm{w}$ Ameryce pojawił się na łamach pisma w 1872 r. Nie ulega wątpliwości, że jego autor był przeciwnikiem

\footnotetext{
Ibidem, 211-216.

5 Początki ruchu kobiecego sięgają połowy XVIII w., w tym czasie idee feministyczne trafiły do szerszego grona osób. Na wzrost aktywności kobiet miały wpływ ideologia oświecenia i rewolucja francuska. W połowie XIX w. kobiety w Ameryce, Europie, Nowej Zelandii i Australii organizowały się już w grupy w celu walki o swoje prawa. Historię emancypacji można podzielić na kilka okresów. Nas będzie interesować period zapoczątkowany w 1860 r., a określany mianem „pierwszej fali” feminizmu, który trwał do 1920 r. Należy pamiętać, że ówczesnym kobietom chodziło nie tylko o przyznanie praw politycznych, lecz także przede wszystkim o równouprawnienie ich na gruncie społecznym i ekonomicznym, chociaż walka o prawa wyborcze była, szczególnie w USA i Wielkiej Brytanii, ważnym postulatem. Priorytetem było jednak umożliwienie podjęcia edukacji w szkołach średnich i wyższych oraz dostęp do pracy, tak by każda $z$ nich, kiedy zostanie pozbawiona opieki
} 
tych teorii, gdyż uważał je za coś przeciwnego naturze, moralności, a nawet zdrowemu rozsądkowi. Twierdził, że pewne idee, które rozwijały się na Nowym Kontynencie, ze względu na różnice kulturowe, ekonomiczne i społeczne na ziemiach polskich nie miały racji bytu. Najwięcej miejsca poświęcono przybliżeniu sylwetki Victorii Woodhull, czołowej amerykańskiej emancypantki tego okresu. W artykule podawano, że jako pierwsza kobieta w historii była właścicielka firmy bankierskiej, poza tym głosiła teorię wolnej miłości i - co najbardziej szokowało publicystów - ubiegała się o fotel prezydenta Stanów Zjednoczonych ${ }^{6}$. Woodhull startowała $z$ ramienia Equal Rights Party w wyborach 1872 r., w których konkurowała $z$ Ulyssesem Grantem i Horace'em Greeleyem ${ }^{7}$.

Ponownie o Woodhull wspomniano w 1882 r., kiedy przyjechała do Europy. Napomykając przy tej okazji, że jej żądania równouprawnienia szły jeszcze dalej, chciała je rozszerzyć na wszystkie sfery życia. W trakcie pobytu poinformowała też o chęci startowania w wyborach prezydenckich w 1884 r. Powatpiewano jednak, by Ameryka była gotowa poprzeć ją w tych staraniach ${ }^{8}$. Okazuje się, że nawet współcześni amerykańscy wyborcy nie są w stanie zaakceptować kobiety na tym stanowisku, forsując nawet bardzo kontrowersyjnych kandydatów.

„Tygodnik Mód i Powieści” zamieszczał zdawkowe i wybiórcze informacje odnośnie do rozwoju ruchu emancypacyjnego w Stanach Zjednoczonych. Nie powinien chociażby przegapić powstania ruchu sufrażystek, które miało miejsce w 1869 r. Należy podkreślić, że w tym roku utworzono dwie niezależne organizacje: National Woman Suffrage Association (NWSA), która kierowały Elizabeth Cady Stanton i Susan

mężczyzny, mogła utrzymać się sama. W wielu krajach ruch ten miał podobne cechy i cele, lecz występowały też różnice narodowe. Na przykład w Stanach Zjednoczonych aktywistki pochodziły przede wszystkim $z$ obszarów wiejskich Nowej Anglii. Oprócz walki o prawa wyborcze angażowały się w ruchy abstynenckie i antyniewolnicze. Postulowały również o podjęcie reform moralnych. Określeniu walki kobiet o równouprawnienie posłużyły następujące terminy: prawa kobiet, emancypacja, ruch kobiet i ruch kobiecy. Zob.: June Hannam, Feminizm, przeł. Agnieszka Kaflińska, (Poznań : Zysk i S-ka, 2010), 11-57; Anna Burzyńska, Michał Paweł Markowski, Teorie literatury XX wieku. Podręcznik, (Kraków : Wydawnictwo Znak, 2007), 391-391; Jean V. Matthews, Women's Struggle for Equality. The First Phase, 1828-1876, (Chicago : Ivan R. Dee, 1997), 3-115; Zbigniew Bokszański (red.), Encyklopedia socjologii, t. 1, (Warszawa : Oficyna Naukowa,1998), 213-215.

6 L.S.W., „Emancypantki amerykańskie”, Tygodnik Mód i Powieści, nr 38, 1872, 1-2.

7 Sara Margaret Evans, Born for Liberty: A History of Women in America, (New York-London : The Free Press : Collier Macmillan Publ., 1989); Carol Hymowitz, Michaele Weissman, A History of Women in America, (New York : Bantam Books, 1978), 163-168.

8 „Z kraju i z zagranicy”, Tygodnik Mód i Powieści, nr 38, 1882, 451-452. 
B. Anthony, oraz American Woman Suffrage Association (AWSA) z Lucy Stone i Henrym Blackwellem na czele. Powstały one w wyniku rozłamu w środowisku działaczek. AWSA postawiła za sobie cel tylko bitwę o przyznanie praw wyborczych, $z$ kolei NWSA próbowała też rozwiązywać wiele innych problemów związanych $z$ równouprawnieniem ${ }^{9}$. Warto nadmienić, że na łamach czasopisma o niektórych wydarzeniach, szczególnie $z$ tak odległego kraju, nie informowano na bieżąco. Nieraz robiono to $z$ kilku-, a nawet $z$ kilkunastoletnim opóźnieniem, przy okazji omawiania innego problemu będącego konsekwencją wcześniejszych zdarzeń.

W 1880 r. w tygodniku zamieszczono artykuł autorstwa George'a Valberta ${ }^{10}$, w którym autor stwierdził, że problem równouprawnienia kobiet był jednym $z$ najbardziej emocjonujących kwestii w ówczesnym świecie. Sam opowiadał się za umiarkowanymi reformami, ograniczonymi do poszerzenia edukacji kobiet i dopuszczenia ich do niektórych zawodów. Nie popierał za to dążeń w przyznaniu praw politycznych. Zgadzał się, że w odróżnieniu od Amerykanów Europejczycy popełniali błąd w wychowaniu kobiet, szykując je na skromne, lękliwe damy, a później wymagali od nich, by poradziły sobie w zmieniajacym się świecie i sprostały nowym oczekiwaniom społecznym. Uważał, że obywatelki Stanów Zjednoczonych, dzięki swojej samodzielności, były lepiej przygotowane do życia w społeczeństwie demokratycznym i mogły ustrzec się wielu pułapek ${ }^{11}$.

Negatywnie na temat emancypacji pisano w cyklu Pogadanka w 1883 r. Uważano, że Polki były zawsze wolne i równe mężczyznom, i nie musiały walczyć o prawa, jak to czyniły Amerykanki i mieszkanki Europy Zachodniej ${ }^{12}$. W tym samym roku „Tygodnik Mód i Powieści” wspomniał o meetingu kobiet, który odbył się w Londynie, a który zaszczyciły swoja obecnością dwie słynne amerykańskie bojowniczki, a mianowicie Elisabeth Cady Stanton i Susan B. Anthony ${ }^{13}$. Podawano, że opowiedziały

\footnotetext{
9 Jean V. Matthews, Women's Struggle for Equality, 142-147; Anna Burzyńska, Michał Paweł Markowski, Teorie literatury, 393-394.

10 Pseudonim Victora Cherbulieza, francuskiego dramaturga, prozaika, eseisty. Posługiwał się nim, pisząc na aktualne tematy polityczne na łamach „Revue des Deux Mondes”. Artykuł cytowany na łamach „Tygodnika Mód i Powieści” pochodził z tego czasopisma. Charles Dudley Warner (red.), A Library of the World's Best Literature, vol. 9, (New York : Cosimo Classics, 2008), 3609-3610.

11 George Valbert, „O emancypacji kobiet”, Tygodnik Mód i Powieści, nr 51, 1880, 601-602.

12 Es. Zet., „Pogadanka”, Tygodnik Mód i Powieści, nr 9, 1883, 102.

13 Warto podkreślić, że tygodnik przekręcił ich nazwiska; pierwszą nazwał Santon, a druga Antony.
} 
one słuchaczom o sytuacji kobiet w Stanach Zjednoczonych i ich sukcesach w walce o dostęp do zawodów zarezerwowanych dla mężczyzn. Wspominano, że wiele $z$ nich pracowało tam jako lekarki, adwokatki, kaznodziejki, dziennikarki, redaktorki czy nauczycielki. Dostrzegano, że kobietom oddawano najgorzej płatne posady, te, których nie chcieli podejmować się mężczyźni. Stwierdzono, że mimo przeszkód amerykańskie działaczki nie poddawały się i nadal zamierzały walczyć o swoje prawa, twierdząc, że „nie wydobędziemy się z niewolniczej podległości, dopokąd nie pozyskamy prawa wyborczego, zupełnie na równi z mężczyznami”"14.

W 1893 r. wspomniano o kongresie Niemek, który odbył się w Norymberdze. Zgromadzone na nim działaczki z zazdrościa przygladały się sytuacji kobiet w Ameryce. Uważały, że Europejki powinny dażyć do takiego ideału. Uznano Stany Zjednoczone za „ziemię obiecana” dla emancypantek. Autor artykułu przestrzegał przed takim myśleniem. Przypominał, że Europę i Stany Zjednoczone różniła historia, a ówczesne stosunki amerykańskie były pokłosiem walki, jaką musieli stoczyć pierwsi osadnicy i kolejni emigranci, a w którą zaangażowały się na równi kobiety. To ukształtowało specyficzny charakter amerykański, podczas gdy Europejczycy mieli o wiele dłuższa historię, a reformy społeczne wprowadzano stopniowo ${ }^{15}$. W podsumowaniu autor jeszcze raz podkreślił, że wzór amerykański był dla Europejek trudny, a nawet niemożliwy do zrealizowania, ponieważ rodzime społeczeństwa były stare, dawno ukształtowane, przez co niechętne do zmian i przeobrażeń. Z kolei Amerykanki mogły zacząć wpływać na swoje położenie już w momencie tworzenia państwowości ${ }^{16}$.

W „Tygodniku Mód i Powieści” kilkukrotnie przytoczono krytyczne poglady wobec kobiet francuskiego publicysty Jeana Jussieu. Wyróżnił on dwa rodzaje feminizmu: intelektualny (równość intelektualna mężczyzn i kobiet) oraz moralny (równa płaca za tę sama pracę). O ile był przeciwnikiem tej pierwszej teorii, o tyle $z$ ta drugą w zasadzie się zgadzał. Apelował jednak o to, by Europejki nie brały Amerykanek za wzór do naśladowania. Redaktor czasopisma, który przybliżał poglądy Francuza, stwierdził z wyraźna ulgą, że problemy te nie dotyczyły Polek. Uważał, że

14 „Z kraju i z zagranicy”, Tygodnik Mód i Powieści, nr 37, 1883, 439.

15 St. M.Rz., „Sprawa kobieca a konieczność dziejowa i ekonomiczna”, Tygodnik Mód i Powieści, nr 45, 1893, 355-356.

16 Ibidem, 364. 
borykały się one $z$ innymi kłopotami, miały odmienne aspiracje i dążenia. Wzywał jednocześnie, aby $z$ dużym krytycyzmem przyjmować wszelkie nowe idee dochodzace $z$ różnych stron i przyjmować tylko te, które przynosily same korzyści ${ }^{17}$.

Do tematu walki o prawa wyborcze kobiet powrócono w 1890 r. przy okazji przyjęcia Wyoming do Unii jako pełnoprawnego stanu. Przypominano, że kobiety od początku miały tam prawo do głosowania (od 1869 r. ${ }^{18}$. Podkreślano, że po wejściu do Unii nie wykreślono tego zapisu. W „Tygodniku Mód i Powieści” dywagowano, że od tej pory kobiety $z$ tego stanu miały prawo do kandydowania do Izby Reprezentantów, Senatu, a nawet startowania w wyborach prezydenckich. W czasopiśmie poniekąd popierano aspiracje polityczne kobiet, ale zastrzegano, że nie powinny one przekraczać pewnych granic ${ }^{19}$.

Na poczatku XX w. na łamach czasopisma $z$ ironia komentowano, że w Stanach Zjednoczonych, mimo prężnie działającego ruchu kobiecego, tylko w czterech stanach kobiety dysponowały prawami wyborczy$\mathrm{mi}^{20}$ : w Wyoming (1869), Utah (1870), Kolorado (1893), Idaho (1896). Przed I wojna światowa prawa wyborcze nadano kobietom jeszcze w: Waszyngtonie, Kalifornii, Arizonie, Oregonie, Kansas, Montanie, Newadzie. Najbardziej postępowe pod tym względem okazały się stany amerykańskiego Zachodu, a najbardziej opierało się przed zmianami Południe ${ }^{21}$. Przyznanie praw wyborczych kobietom w niektórych stanach, a także stopniowe dopuszczanie ich do stanowisk publicznych było częściowym zwycięstwem ruchu.

W 1901 r. pisano, że kobiety z chęcią korzystały z przyznanego im prawa wyborczego, mimo że mężczyźni liczyli na to, iż zadowolą się one tylko samym zapisem ${ }^{22}$. W innej notce informowano o tym, że kobiety przeprowadzały się chętniej do tych stanów amerykańskiego Zachodu,

\footnotetext{
17 T.M., „Bankructwo intelektualizmu kobiecego: (w opracowaniu I. Jussieu)”, Tygodnik Mód i Powieści, nr 27, 1903, 317.

18 Izabela i Wojciech Kosteccy, 50 + 1. Kalejdoskop stanów Ameryki, (Warszawa : „Linia”, 1991), 108.

19 „Z chwili bieżącej: Równouprawnienie kobiety”, Tygodnik Mód i Powieści, nr 44, 1890, 351.

20 K., „Ze spraw kobiecych”, Tygodnik Mód i Powieści, nr 30, 1902, 354.

21 Patricia Nelson Limerick, „Amerykański Zachód. 1848-1917”, w: Walter Nugent, Halina Parafianowicz (red.), Historia Stanów Zjednoczonych Ameryki, t. 3, (Warszawa : PWN, 1995), 114; David Mauk, John Oakland, Cywilizacja amerykańska, przeł. Monika J. Dykier, (Wrocław : Astrum, 1999), 83.

${ }^{22}$ R., „Ze świata kobiecego”, Tygodnik Mód i Powieści, nr 1, 1901, 4.
} 
które nadały im prawa wyborcze. Podkreślano, że nowy przywilej nie przeszkadzał im w realizacji obowiązków domowych ${ }^{23}$. Z kolei Halina Duninówna w 1912 r. zauważyła, że równouprawnienie przyniosło w USA wiele korzyści ${ }^{24}$.

W „Tygodniku Mód i Powieści” co pewien czas przybliżano sylwetki kobiet, które walczyły o prawa polityczne. Jedna $z$ nich była Belva Ann Lockwood - prawniczka, pedagog, polityk. W 1891 r. polski tygodnik podawał, że w ostatnich wyborach kandydowała na prezydenta Stanów Zjednoczonych ${ }^{25}$. Autor artykułu, Anatol Krzyżanowski ${ }^{26}$, a właściwie autorka, nie dziwiła się tym aspiracjom, ponieważ dostrzeżono, że w niektórych stanach kobiety miały prawo do głosowania, a nawet zajmowały wysokie stanowiska urzędnicze, np. pełniły funkcję burmistrza ${ }^{27}$.

\section{Szkolnictwo}

Watek edukacji Amerykanek nie został na łamach „Tygodnika Mód i Nowości" dostatecznie omówiony. Podawano jedynie ogólne informacje o wybranych problemach. Pierwsze wzmianki na ten temat zamieszczono w 1869 r. Pochodziły one $z$ fragmentów klasycznej już publikacji Alexisa de Tocqueville'a pt. O demokracji w Ameryce, która zawiera wnikliwą analizę społeczeństwa amerykańskiego. Mimo że pierwszy tom dzieła wydano w 1835 r., a drugi w 1840 r., wiele obserwacji francuskiego myśliciela politycznego i dyplomaty było uniwersalnych, a jego praca stała się wzorem dla rzeszy innych pisarzy, w tym Henryka Sienkiewicza.

Zaprezentowane w „Tygodniku Mód i Nowości” uwagi Tocqueville'a dotyczyły rozwoju szkolnictwa elementarnego i jego wpływu na

\footnotetext{
${ }_{23}$ T., „Prawa polityczne kobiet”, Tygodnik Mód i Powieści, nr 22, 1908, 4.

24 Halina Duninówna, „Współpraca kobiet w gminie i w parlamencie”, Tygodnik Mód i Powieści-Nasz Dom, nr 26, 1912, 1.

${ }_{25}$ Warto wspomnieć, że Belva Ann Lockwood była pierwszą kobietą, która wywalczyła w USA prawo występowania przed Sądem Najwyższym. Jako pierwsza miała też zaszczyt widnieć na kartach do głosowania, będąc kandydatką na prezydenta w wyborach w 1884 i 1888 r. Reprezentowała National Equal Rights Party. F.F.P., „Lockwood, Belva Ann Bennett”, w: Dumas Malone (ed.), Dictionary of American Biography, vol. 11, (New York : Charles Scribner's Sons, 1933), 341.

${ }^{26}$ Pod tym pseudonimem ukrywała się Natalia Korwin-Szymanowska, z domu Krzyżanowska. Encyklopedia PWN, [Dostęp: 27.02.2019]. Dostępny w World Wide Web: <https:/ / bit.ly/38GlHhe>.

27 Anatol Krzyżanowski, „Kronika działalności kobiecej”, Tygodnik Mód i Powieści, nr 46, 1891, 362-363.
} 
niebywały postęp, jaki nastapił w Stanach Zjednoczonych. Francuski myśliciel dostrzegł, że zawód nauczyciela w tym typie szkół zdominowały kobiety $^{28}$. Ze zdziwieniem zauważył, że Amerykanie, w przeciwieństwie do Europejczyków, $z$ chęcia powierzali im tę rolę, ponieważ uważali, że miały lepsze podejście do dzieci i młodzieży. $Z$ cała pewnością niebagatelna rolę odgrywało to, że zawód ten był mało opłacany. $Z$ tego powodu mężczyźni nie byli zainteresowani podjęciem zatrudnienia w tym charakterze. Do innych wad szkolnictwa elementarnego w USA można zaliczyć młody wiek nauczycielek i zwiazane $z$ tym niskie kwalifikacje oraz małe doświadczenie. To też miało ścisły związek $z$ niska pensją ${ }^{29}$.

W omawianym czasopiśmie zwrócono uwagę na to, że system edukacji kobiet i zakres ich działalności rozwijał się bardzo szybko, a przodowały w tym Stany Zjednoczone. Kobiety miały możliwość nauki nie tylko w szkołach średnich i wyższych, lecz także podjęcia pracy w zawodach tradycyjnie zarezerwowanych dla mężczyzn (prawnik, lekarz, bankier) ${ }^{30}$. Autor jednego $z$ artykułów przesadnie idealizował sytuację w USA, ponieważ tak naprawdę kobiety, chcąc realizować tam swoje marzenia, nieraz musiały przezwyciężyć wiele trudności i uprzedzeń oraz wykazać się wyjatkową determinacja. Nie było im łatwo pokonać stereotypy w zawodach, takich jak lekarz czy prawnik. Podkreślano też, że Amerykanki nie poprzestały na walce o dostęp do edukacji oraz „męskich” zawodów, coraz głośniej postulowały o przyznanie im praw politycznych. Stwierdzono jednak, że nawet tam uważano ten postulat za daleko posunięty ${ }^{31}$.

O wspólnym kształceniu kobiet i mężczyzn na łamach tygodnika pisano w 1893 r. W Stanach Zjednoczonych na niższych szczeblach edukacji było ono czymś powszednim, w Europie natomiast przyglądano się temu zjawisku $z$ dużą rezerwa. Warto zauważyć, że koedukacja na poziomie szkół elementarnych była podyktowana względami ekonomicznymi, szczególnie na Zachodzie, gdzie sieć osadnicza nie rozwinęła się jeszcze w dostatecznym stopniu, ale też i w wielkich miastach. Wspólne kształcenie zapoczatkowano w szkolnictwie elementarnym, później rozszerzając je na inne typy szkół. Zwolennicy twierdzili, że taka edukacja nie będzie

\footnotetext{
28 Alexis de Tocqueville, „Wychowanie publiczne w Ameryce, i jaki udział przejmuja w niem kobiety", Tygodnik Mód i Powieści, nr 6, 1869, 1-2.

29 Ibidem, Tygodnik Mód i Powieści, nr 7, 1869, s. 1.

30 S.-z., „Działalność kobiet za granicami rodziny”, Tygodnik Mód i Powieści, nr 42, 1879, 493.

31 Ibidem, 493-494.
} 
stanowić zagrożenia dla moralności, a wręcz przeciwnie - przyniesie obu płciom wiele korzyści. Zaobserwowano, że dzięki wspólnemu obcowaniu mężczyźni nabierali towarzyskiej ogłady, z kolei kobiety skromności, ponieważ panowie byli stróżami przyzwoitości ${ }^{32}$.

Można się domyślać, że metody wychowawcze Amerykanów mogły być dla Europejczyków, przywykłych do innych wzorców, bardzo ekscentryczne, a wręcz szokujące. Na Starym Kontynencie ograniczano możliwość wzajemnych kontaktów wśród młodych przeciwnej płci, uznając je za zagrażające moralności. Niestosowne było też wychodzenie kobiet bez przyzwoitki. W związku $z$ tym wspólne kształcenie, które w Stanach Zjednoczonych $z$ powodzeniem praktykowano, było w Europie wręcz nie do pomyślenia i odrzucane jako nierealne do zrealizowania ${ }^{33}$.

Z kolei cytowany wcześniej Jean Jussieu był przeciwnikiem koedukacji i dowodził niższości umysłu kobiety. Podkreślał, że dominowały one $\mathrm{w}$ nauczaniu jedynie $\mathrm{w}$ klasach niższych, a na poziomie uniwersyteckim i w dalszej karierze naukowej rysowała się zdecydowana przewaga mężczyzn, ponieważ mieli oni zdolność pracy twórczej i tworzenia oryginalnych dzieł. Nie przyjmował do wiadomości żadnych tłumaczeń. Jego zdaniem kobiety miały wystarczająco dużo czasu, by wypracować pozycje w społeczeństwie ${ }^{34}$.

\section{Praca}

W drugiej połowie XIX w. bardzo ważna kwestią było umożliwienie kobietom podjęcia pracy zawodowej, ponieważ zmieniające się warunki społeczno-ekonomiczne zmusiły je do wyjścia poza mir domowy. Na łamach „Tygodnika Mód i Powieści” podkreślano, że przez wiele wieków pozycję kobiety marginalizowano, ograniczając jej rolę do życia rodzinnego, a nawet ją ubezwłasnowolniając i utrzymując w zależności od męż$\operatorname{czyzn}^{35}$. Zdawano sobie sprawę, że zmiana podejścia, choć niezbędna, nie

\footnotetext{
32 A.S., „Wychowanie mieszane”, Tygodnik Mód i Powieści, nr 18, 1894, 140-141.

33 Ibidem.

34 Anna Stocka, „Problematyka amerykańska na łamach "Tygodnika Mód i Powieści» w latach 1900-1914", w: Łukasz Niewiński, Czas wojny, czas pokoju, t. 2, (Oświęcim : Napoleon V, 2015), 17.

35 S.-Z., „Działalność kobiet za granicami rodziny”, Tygodnik Mód i Powieści, nr 41, 1879, 481-482.
} 
będzie łatwa i napotka duży opór. Nie tylko to musiało ewoluować, ale przede wszystkim podejście do ich wychowania ${ }^{36}$.

W „Tygodniku Mód i Powieści” podkreślano, że kobiety w USA przecierały szlaki w zawodach tradycyjnie zarezerwowanych dla mężczyzn i liczba wykonywanych przez nie profesji stale rosła. Więcej miejsca poświęcono ich staraniom o zaistnienie w zawodzie lekarskim. Zwracano uwage na to, że nie było im łatwo przezwyciężyć uprzedzenia i podjać praktykę w tej profesji. Ogólnych informacji na ten temat „Tygodnik Mód i Powieści" dostarczył w 1882 r. W artykule podawano, że pierwsza lekarka w Ameryce była Elisabeth Blackwell. Błędnie jednak poinformowano, że studia ukończyła w Genewie, a tak naprawdę w Nowym Jorku, w Geneva Medical College. Pisano też, że wraz z siostra Emily i Maria Zakrzewska, lekarka pochodzenia polskiego, założyły w Nowym Jorku szpital. Zaznaczano, że tylko w ten sposób mogły prowadzić własną praktykę lekarska, ponieważ inne placówki nie miały zaufania do kobiet lekarzy i nie chciały ich zatrudniać. Dodawano, że Zakrzewska utworzyła podobny szpital również w Bostonie ${ }^{37}$.

Na łamach „Tygodnika Mód i Powieści” o kobietach lekarkach pisano niejednokrotnie. Kolejny raz do tego tematu powrócono w 1889 r., kiedy dość szczegółowo przybliżono karierę Elisabeth Blackwell, wspominając przy okazji o rodaczce Marii Zakrzewskiej. Wyjaśniano, że w USA działały trzy szkoły wyższe kształcące kobiety na lekarzy: w Nowym Jorku - Woman's Medical College, Bostonie - New England Female Medical College i Filadelfii - Woman's Medical College of Pennsylvania ${ }^{38}$. Domyślano się, że Amerykanki musiały odnosić pewne sukcesy zawodowe, skoro niektóre $z$ nich pełniły funkcję szefów klinik czy też były profesorami szkół medycznych. Zauważono, że w USA pracowało już kilka tysięcy lekarek ${ }^{39}$.

\footnotetext{
36 Ibidem.

37 „Z kraju i z zagranicy”, Tygodnik Mód i Powieści, nr 19, 1882, 223.

38 Placówkę w Nowym Jorku utworzyły Elizabeth i Emily Blackwell wraz z Zakrzewska. Ta ostatnia w 1859 r. przeniosła się do Bostonu, by wykładać w New England Female Medical College, a w 1862 r. utworzyła tam szpital, w którym przyjmowała kobiety i dzieci. Po Nowym Jorku był to drugi szpital kierowany przez kobietę. Obecnie nosi nazwę Dimock Community Health Center. Lisa Tendrich Frank (ed.), Women in American Civil War, vol. 1, (Santa Barbara : ABC-CLIO, 2008), 601; Virginia G. Drachman, „Female Solidarity and Professional Success: the Dilemma of Women Doctors in Late Nineteenth-Century America", Journal of Social History, vol. 15, no. 4, 1982, 607-619.

39 Anatol Krzyżanowski, „Kobieta-lekarz XIX wieku. Rozprawa doktoryzacyjna pani Karoliny Szulcówny”, Tygodnik Mód i Powieści, nr 11, 1889, 82.
} 
W 1891 r. w „Tygodniku Mód i Powieści” pisano o tym, że kobiety w zawodzie lekarza odnosiły w Stanach Zjednoczonych wiele sukcesów $\mathrm{i}$ ich pozycja była ugruntowana. Miało o tym świadczyć to, że jedna $z$ lekarek otrzymała posadę profesora ginekologii na chicagowskiej uczelni medycznej dla kobiet. Zwracano uwagę, że w środowisku medycznym krok ten spotkał się $z$ krytyką wśród niektórych mężczyzn. Niemniej jednak $z$ ulga odnotowano, że nie wpłynęło to na zmianę decyzji ${ }^{40}$. Amerykanki sporo osiagnęły $\mathrm{w}$ dziedzinie medycyny, choć nie należy przeceniać ich znaczenia. $Z$ pewnością miały większe możliwości podjęcia pracy w tym zawodzie niż w innych krajach na świecie. Cały czas musiały jednak walczyć $z$ wieloma uprzedzeniami oraz męską dominacją i wrogością środowiska.

W kolejnym artykule opublikowanym w 1891 r. opisano szkoły medyczne dla kobiet. Autor na początku zastrzegł, że nie zamierza powielać stereotypowych opinii na ten temat, według których $z$ jednej strony stały one na słabym poziomie, $z$ drugiej zaś, że kobiety mogły bez przeszkód realizować swoje aspiracje zawodowe, mając nieskrępowany dostęp do wszelkiego rodzaju uczelni. Do omówienia tego tematu posłużono się praca dr. Henry'ego Sterna z Nowego Jorku. Jego zdaniem w USA ruch emancypacji kobiet cały czas miał swoich przeciwników, wszystko zaś, do czego doszły w dziedzinie medycyny, mogły zawdzięczać jedynie swojej determinacji i pracy. Tak naprawdę tylko dzięki tworzeniu własnych uczelni, szpitali i różnego rodzaju towarzystw miały szansę zaistnieć w tym zawodzie. Podkreślał dobitnie, że nie było im łatwo przebić się przez uprzedzenia środowiska lekarskiego, a także samego społeczeństwa, które darzyło nieufnością kobiety pracujace w tym zawodzie ${ }^{41}$.

Henry Stern wyjaśniał, że szkoły medyczne dla kobiet dzieliły się na alopatyczne ${ }^{42}$, homeopatyczne i zbiorowe. Dwie pierwsze powoływano wyłącznie na ich potrzeby, a trzeci typ służył studentom obu płci. Autor nadmienił, że skoro kobietom pozwolono kształcić się w tym zawodzie (szkoły w Filadelfii i Bostonie), to istniała potrzeba stworzenia placówki, w której swoją wiedzę teoretyczna mogły wykorzystywać w praktyce. Temu celowi miał służyć szpital w Nowym Jorku o nazwie The New

40 „Kronika działalności kobiecej: z Ameryki”, Tygodnik Mód i Powieści, nr 10, 1891, 77.

41 Rz., „Uniwersytety niewieście w Stanach Zjednoczonych”, Tygodnik Mód i Powieści, nr 38, 1891, 299.

42 Inaczej medycyna naukowa, współczesna czy zachodnia. 
York Infirmary for Women and Children. Stern nie wspomniał, że za jego powołaniem stały trzy słynne amerykańskie lekarki: Elisabeth i Emily Blackwell oraz Maria Zakrzewska. Warto też zaznaczyć, że o powstałym w 1859 r. szpitalu „Tygodnik Mód i Powieści” pisał już kilka lat wcześniej. Dzięki determinacji kobiet udało się także powołać uczelnię przy tej placówce (Women's Medical College). Stern dodawał, że fakt ten w pełni nie usatysfakcjonował Amerykanek, ponieważ chciały mieć dostęp do męskich uczelni medycznych, gdyż dysponowały one większymi środkami pieniężnymi i zapleczem niż nowo założone uczelnie dla kobiet ${ }^{43}$. Poza tym w Nowym Jorku działały dwie inne uczelnie medyczne dla kobiet: homeopatyczny New York Medical College ${ }^{44}$ i Eclectic Medical College ${ }^{45}$. Redakcja „Tygodnika Mód i Powieści” nie przytoczyła całego artykułu, tłumacząc się brakiem miejsca, niemniej jednak była pod wrażeniem inicjatyw Amerykanek i ich determinacji.

W tygodniku co pewien czas przybliżano biogramy znanych kobiet, które realizowały się w zawodach tradycyjnie zarezerwowanych dla mężczyzn. Takim przykładem mogła być Judith Ellen Horton Foster ${ }^{46}$ ze stanu Iowa, która wraz z mężem prowadziła praktykę adwokacką. Podawano, że to właśnie on - sławny prawnik - namówił ją na kształcenie się w tym zawodzie. Podkreślano przy tej okazji, że obowiąki zawodowe nie

\footnotetext{
43 Rz., „Uniwersytety niewieście”, 299-300.

44 Istnieje od 1860 r., osobny oddział dla kobiet utworzyła w 1863 r. Clemence Sophia Lozier, który zamknięto w $1918 \mathrm{r}$. Lekarze $\mathrm{z}$ tej uczelni praktykowali w istniejącym od 1875 r. Metropolitan Hospital. New York Medical College, [Dostęp: 16.07.2018]. Dostępny w World Wide Web: <https://www.nymc.edu/about-nymc/history/>.

45 Medycyna eklektyczna była jedną $z$ gałęzi medycyny amerykańskiej, która rozwinęła się w XIX w. Leczenie opierano na medycynie naturalnej, ziołolecznictwie, medycynie indiańskiej. Marc Micozzi, Fundamentals of Complementary and Alternative Medicine, (St. Louis : Saunders/Elsevier, 2011), 302.

46 Warto dodać, że Judith Ellen Horton Foster (1840-1910) była jedna z najbardziej wpływowych kobiet w tym stanie. Jako czwarta kobieta w historii mogła występować przed Sądem Najwyższym stanu Iowa. Opowiadała się za prohibicją i czynnie walczyła o jej wprowadzenie. Była przewodniczaca komisji prawnej Woman's Christian Temperance Union. W 1887 r. odwiedziła Europę jako wysłanniczka prezydenta, by zbadać warunki bytowe żołnierzy amerykańskich biorących udział w wojnie hiszpańsko-amerykańskiej. W 1900 r. prezydent William Taft wysłał ją z misja na Filipiny, aby skontrolowała położenie tamtejszych kobiet i dzieci. W 1902 r. wyznaczono ja jako przedstawiciela Stanów Zjednoczonych na konferencję Czerwonego Krzyża, która odbywała się w Petersburgu. W 1906 r. prezydent Theodore Roosevelt skierował ją do zbadania sytuacji kobiet i dzieci pracujacych w więzieniach, a w 1908 r. kontrolowała byt więźniarek w więzieniach stanowych i federalnych. David C. Mott, „Judith Ellen Foster”, The Annals of Iowa, vol. 19, no. $2,1933,126-138$.
} 
kolidowały z jej życiem rodzinnym i prowadzeniem domu ${ }^{47}$. Warto dodać, że była pierwszą kobietą adwokatem w stanie Iowa. Poza tym pracowała jako wykładowca oraz aktywnie działała na rzecz ruchów antyalkoholowych. Z kolei jako członek Woman's Christian Temperance Union czynnie uczestniczyła w pracach legislacyjnych tej organizacji ${ }^{48}$.

W 1897 r. na łamach tygodnika opublikowano artykuł, w którym Ellen Foster odpowiadała na zarzuty przeciwników działalności kobiecej. Swoją odezwę zamieściła na łamach „North American Review”. Pisała, że kobiety oskarżano o zaborczość, ponieważ wdzierały się w różne dziedziny życia społecznego i politycznego. Pani Foster nie zgadzała się z tym, argumentując, że działalność społeczna leżała w Ameryce odłogiem, była dziedzina niczyja, wobec tego przejęcie jej przez kobiety nie powinno nikogo bulwersować, nikt też nie może ganić ich za działalność filantropijna, z której korzystało całe społeczeństwo. Broniła także mniej zamożnych Amerykanek, które zamiast siedzieć w domu poszły do pracy, aby poprawić sytuację materialna rodziny. Podkreślała, że praca zarobkowa to w wielu wypadkach konieczność, a nie moda, zachcianka czy kaprys, jak to przedstawiali mężczyźni. Według niej niesprawiedliwe było również karanie kobiet za to, że pracowały poza domem, uczyły się, dzięki temu poznawały świat, stawały się bardziej wykształcone i oświecone, a co zatem idzie - mniej podatne na wpływy i manipulacje ${ }^{49}$.

W 1896 r. przybliżono artykuł, który wyszedł spod pióra francuskiego podróżnika, pisarza i dyplomaty Charles'a de Varigny. Opisywał on w nim dwie wybitne kobiety: Amerykankę Hetty Green, najbogatsza kobietę w Nowym Jorku, a w zasadzie w całych Stanach Zjednoczonych, oraz równie majętną i wpływową Chilijkę. Jak podawał de Varigny, Hetty Green urodziła się w Bedford (Massachusetts) w rodzinie bogatych kwakrów. Po śmierci ojca i ciotki odziedziczyła spory majątek, którym umiejętne zarządzała, pomnażając go na giełdzie. Prowadziła też różnego rodzaju inwestycje oraz oszczędne, a wręcz skape życie ${ }^{50}$. W artykule autor podał tylko ogólne informacje na temat najbogatszej Amerykanki,

\footnotetext{
47 „Kronika działalności kobiecej: z Ameryki”, Tygodnik Mód i Powieści, nr 5, 1891, 37.

48 Jana Brubaker, „Foster, Judith Ellen Horton (1840-1910)”, w: Jack S. Blocker, David M. Fahey, Ian R. Tyrrell (eds.), Alcohol and Temperance in Modern History: an International Encyclopedia, vol. 1, (Santa Barbara : ABC-CLIO, 2003), 246-247.

${ }^{49}$ K., „Ewolucja społeczna i polityka kobiety w Stanach Zjednoczonych”, Tygodnik Mód i Powieści, nr 52, 1897, 513-514.

50 Charles de Varigny, „Dwie postacie kobiece”, Tygodnik Mód i Powieści, nr 28, 1896, 219-220.
} 
a była to bardzo barwna postać, szczególnie znana ze swojego skapstwa. Może niektóre wiadomości na jej temat nie były jeszcze znane albo nie chciał eksponować jej ekscentryczności, skupiając się bardziej na zdolnościach finansowych.

\section{Wystawa kolumbijska}

W 1893 r. w Stanach Zjednoczonych odbyła się kolejna wystawa światowa. Zorganizowano ją w Chicago dla upamiętnienia 400-lecia odkrycia Ameryki przez Krzysztofa Kolumba. Jej inicjatorem był pochodzacy z Królewca dr Karol Zaręba. Wystawa kolumbijska, jak ją nazywano, niewatpliwie odniosła wielki sukces, również finansowy ${ }^{51}$. Na tak doniosłym wydarzeniu nie mogło zabraknać kobiet.

W roku poprzedzajacym wystawę specjalny komitet powołany przez Kongres amerykański do organizacji oddziału kobiecego rozesłał do wszystkich czasopism kobiecych na świecie odezwę zachęcająca do wzięcia udziału w tym wydarzeniu. Informowano w niej, że postanowiono nie oddzielać wyrobów kobiecych od męskich, chociaż zamierzano wydzielić dla nich specjalny gmach, ale miały się tam znaleźć tylko najlepsze produkty ${ }^{52}$. Wyrażano przy tej okazji nadzieję, że wystawa kolumbijska będzie promocją wytwórczości kobiecej, bo do tamtej pory była ona mało znana i zepchnięta na dalszy plan ${ }^{53}$. Na czele komitetu organizacyjnego do spraw kobiecych stała Bertha Palmer, żona jednego $z$ chicagowskich milionerów Pottera Palmera, która $z$ pełnym zapałem zabrała się do zorganizowania tego działu ${ }^{54}$.

W „Tygodniku Mód i Powieści” zawiadamiano, że w Petersburgu powstał specjalny podkomitet, który poprosił warszawski oddział Towarzystwa Przemysłu i Handlu, żeby umożliwił kobietom zaprezentowanie

\footnotetext{
51 Szczególnie uroczyście obchodzono to wydarzenie w Chicago w 1892 r. Z kolei inauguracja samej wystawy nastapiła 1.05.1893 r. i była bardzo spektakularna. Budowle wystawowe robiły duże wrażenie na zwiedzających. Wzięło w niej udział 45 państw z całego świata, w tym 17 europejskich. Niektóre $z$ nich miały własne gmachy, podobnie jak część stanów amerykańskich. Anna M. Drexlerowa, Polska i Polacy na powszechnych wystawach światowych 1851-2001, (Warszawa : Instytut Sztuki PAN, 2005), 139-143.

52 Anatol Krzyżanowski, „Wystawa w Chicago”, Tygodnik Mód i Powieści, nr 34, 1892, 267-268.

53 Ibidem.

54 Robert Muccigrosso, Celebrating the New World: Chicago's Columbian Exposition of 1893, (Chicago : Ivan R. Dee, 1993), 136-137.
} 
się na wystawie w Chicago. Apelowano przy tej okazji, by poza eksponatami wysyłać informacje o zakładach naukowych, filantropijnych, wychowawczych, rzemieślniczych itp. działajacych na danym obszarze. Przypominano też autorkom dzieł, aby opisały swoje eksponaty w celu ich właściwego zakatalogowania. Komitet petersburski zobowiązał się na swój koszt przewieźć je na miejsce, zadbać o ich bezpieczeństwo w trakcie transportu, odpowiednie wyeksponowanie i udekorowanie działu, a także o bezpieczny powrót do kraju. Szukano takich produktów, które wyróżniały się dobrym wykonaniem i mogły przykuć uwagę zwiedzających. Zachęcano do przekazywania nie tylko najnowszych dokonań, lecz także pożądane były wszelkie dzieła wykonane przez kobiety w minionych wiekach, tak aby móc chronologicznie przedstawić postęp i rozwój działalności kobiecej ${ }^{55}$.

Na początku stycznia 1893 r. zapowiedziano, że kobiety, które zdecydowały się pokazać swoje wyroby w Chicago, będa miały możliwość porównać je $z$ innymi wytworami, ponieważ Towarzystwo Przemysłu i Handlu zorganizowało w swojej siedzibie wystawę tymczasową. Do jej obejrzenia zachęcano wszystkich zainteresowanych. Zastrzegano, że za ocean popłyna jedynie te okazy, które na to zasługiwały. Zawiadamiano, że komitet organizacyjny zdecydował się przygotować specjalną monografię opisująca działalność kobieca na ziemiach polskich, która zamierzano przetłumaczyć na język angielski. Autor artykułu apelował do czytelniczek o dostarczenie informacji źródłowych do tej broszury, szczególnie o ich działalności filantropijnej ${ }^{56}$. W kolejnych numerach wymieniono autorki i okazy, które przesłano na wystawę w Chicago. Dominowały wśród nich wyroby włókiennicze, obrazy, sztuczne kwiaty ${ }^{57}$.

Ciekawostką była wiadomość zamieszczona w jednym $z$ ostatnich numerów $z$ roku 1892, w której przestrzegano młode kobiety przed wyjazdem do Chicago na wystawę albo do pracy w tamtejszych restauracjach i kawiarniach. Obawiano się, że rekrutacja zajmowali się nieuczciwi agenci, którzy zarabiali na handlu „żywym towarem”. Bano się,

\footnotetext{
55 Anatol Krzyżanowski, „Z dziejów pracy niewieściej”, Tygodnik Mód i Powieści, nr 39, $1892,307$.

56 Idem, „Dział kobiet naszych na wystawie w Chicago”, Tygodnik Mód i Powieści, nr 1, 1893, 1-2.

57 „Z chwili bieżącej”, Tygodnik Mód i Powieści, nr 4, 1893, 30.
} 
że kobiety mogły trafić nie do Chicago, a do haremów i domów rozpusty na Wschodzie ${ }^{58}$.

W kolejnym doniesieniu pisano o tym, że w Chicago powstał duży gmach, który miał pomieścić nie tylko wszelkie okazy wytwórczości kobiecej, lecz także biuro informacyjne, dział wychowania, modele ochronek i szkółek, bibliotekę $z$ dziełami napisanymi przez kobiety, zbiory etnograficzne, opisy zakładów dobroczynnych i naukowych założonych lub prowadzonych przez kobiety ${ }^{59}$. Podawano, że pawilon zbudowano w dogodnym miejscu, przy jednym $z$ wejść i w połowie na wodzie, co musiało dawać spektakularny efekt. Komitet organizacyjny z Betą Palmer na czele zadbał też o to, by w miasteczku wystawowym powstał budynek, w którym znalazły się pokoje dla pań i ich rodzin, w innym budynku natomiast zorganizowano dla zwiedzających miejsce opieki nad dziećmi ${ }^{60}$.

Na łamach „Tygodnika Mód i Powieści” zamieszczono krótki opis ekspozycji. Dla autora najbardziej zajmujacy okazał się dział wychowawczy połączony $z$ filantropijnym, w którym zaprezentowano m.in. jak zorganizowano tam szkoły, pracownie kobiece, żłobki i ochronki. Jego zdaniem warto było go obejrzeć, ponieważ Amerykanie znacznie wyprzedzili pod tym względem Europę. W dziale naukowym autor nie dojrzał nic zajmującego, chociaż prace zaprezentowane tam „dowodzą wielkiej wytrwałości, skrzętności i znajomości rzeczy”, dział sztuki w jego opinii „jest tylko zbiorem miernot, często gorzej niż miernot”. Również dział przemysłowo-rękodzielniczy nie zyskał uznania zwiedzającego ${ }^{61}$. W „Tygodniku Mód i Powieści” bardzo pobieżnie opisano eksponaty zgromadzone na wystawie, nawet te wykonane przez kobiety. Nie informowano również, jak ekspozycja $z$ ziem polskich zaprezentowała się na tle innych państw.

Na łamach „Tygodnika Mód i Powieści” informowano, że w czasie trwania wystawy odbył się kongres kobiet. Podawano, że jego obrady były burzliwe i przyciagały wiele osób, w tym mężczyzn, którzy z ciekawościa przysłuchiwali się kongresowiczkom. Miały one wiele do powiedzenia, ponieważ treść wypowiedzi „płynie z ust tej połowy ludzkości, która dotąd milczała i zawsze była zagadka”. Autor był zachwycony tym, że po przemówieniach atmosfera nabierała ,jasności i przejrzystości” i pojawiała się

\footnotetext{
58 „Z chwili bieżącej”, Tygodnik Mód i Powieści, nr 51, 1892, 399.

59 „Z Tygodnia”, Tygodnik Mód i Powieści, nr 38, 1892, 302.

60 Anatol Krzyżanowski, „Pawilon pracy kobiecej w Chicago”, Tygodnik Mód i Powieści, nr 23, 1893, 180-181.

${ }^{61}$ X., „Z Chicago”, Tygodnik Mód i Powieści, nr 37, 1893, 293.
} 
wiara w to, że zmiany w społeczeństwie, o których panie wspominały, na pewno nadejda ${ }^{62}$.

\section{Inne formy aktywności}

Jedna $z$ ważniejszych sfer działalności publicznej Amerykanek było tworzenie klubów kobiecych. Pierwsze $z$ nich powstały w Bostonie i Nowym Jorku w 1868 r. W ciagu kilkudziesięciu lat ich liczba stale rosła, co w 1890 r. doprowadziło do utworzenia Powszechnej Federacji Klubów Kobiecych (General Federation of Women's Clubs, GFWC). W pierwszych latach działalności do głównych zadań tego typu stowarzyszeń należało samodoskonalenie i rozwój intelektualny. $Z$ biegiem lat pole ich aktywności rozszerzało się na rozwiąywanie różnych problemów społecznych $^{63}$.

W „Tygodniku Mód i Powieści” pisano o tym, że Amerykanki czynnie działały w różnego rodzaju klubach. Autor uważał, że Europejki pod tym względem powinny brać $z$ nich przykład, ponieważ były daleko w tyle. Ich rolę zobrazowano na przykładzie założonego w 1868 r. w Nowym Jorku Stowarzyszenia Kobiet Pracujacych (Working Women's Association, WWA). Informowano, że utrzymywało się ono $z$ opłat wniesionych przez członkinie. Nie były one wygórowane, ale konieczne, by regulować rachunki i rozwijać swoją działalność. Stowarzyszenie przyciagało nowe członkinie, gdyż na początku kierowała nimi ciekawość, chęć rozrywki i możliwość uczestniczenia w tego typu inicjatywach. Po aklimatyzacji każda $z$ robotnic wyciagała $z$ uczestnictwa wymierne korzyści. Miały tam możliwość podniesienia swoich kwalifikacji zawodowych, ale też zdobycia wielu cennych, potrzebnych w każdym zawodzie informacji, które ułatwiały im życie. Organizowano różnego rodzaju pogadanki, które miały uświadamiać kobiety na różnych płaszczyznach. Zdaniem autora nie wszystkie amerykańskie rozwiąania dało się przenieść na grunt polski, ale i nie było takiej potrzeby. Optował, by wziąć z każdego tamtejszego stowarzyszenia ,jego ducha, nie formę, duchem jest energia, poczucie potrzeby solidarności w pracy, a tem samem stowarzyszanie się w imię tej pracy"64.

\footnotetext{
62 Ibidem.

63 Sylwia Kuźma-Markowska, Zdrowe matki, chciane dzieci. Ruch kontroli urodzeń w stanie Illinois (1923-1941), (Warszawa : Neriton, 2009), 32-37.

64 A.S., „Stowarzyszenia za Oceanem”, Tygodnik Mód i Powieści, nr 2, 1894, 170-171.
} 
Za wartą opisania w „Tygodniku Mód i Powieści” uznano powołana przez Josephine Shaw Lowell Consumers' League of New York, ponieważ uważano, że takie przedsięwzięcie przydałoby się również na ziemiach polskich. Celem wieloletniej działaczki społecznej, która stworzyła organizację świadomych konsumentów, było przekonanie społeczeństwa do kupowania produktów tylko od uczciwych pracodawców. Za złe położenie mas pracujących winiła nie tylko przedsiębiorców, lecz także wszystkich Amerykanów, którzy się u nich zaopatrywali65.

W 1901 r. na łamach czasopisma omówiono projekt utworzenia w Warszawie pierwszego klubu kobiecego wzorowanego na amerykańskich. Zauważano, że w dużych miastach USA takich stowarzyszeń było nawet kilkadziesiąt. Polskie miało być przeznaczone dla kobiet pracujących, które nie miały żadnych innych rozrywek niż praca i nie stać je było na bywanie na koncertach i balach ${ }^{66}$.

Ciekawostka była też informacja o tym, że w Stanach Zjednoczonych istniały stowarzyszenia zorganizowane przez Polki. W 1908 r. opisano kolejny zjazd Zwiąku Polek w Ameryce ${ }^{67}$, na którym złożono sprawozdanie $z$ działalności, apelowano też o to, by wychowywać dzieci nie tylko w duchu poszanowania prawa państwa, w którym aktualnie mieszkały, lecz także przekazywać tradycje kraju pochodzenia, krzewiąc „w ich duszach miłość względem ojczyzny - Polski” i zapoznając $z$ „wielka narodowa sprawa”68. Warte podkreślenia sa zamieszczone w tym miejscu dość śmiałe hasła narodowe.

Amerykanki angażowały się też w ruchy na rzecz trzeźwości. W Polsce problem alkoholizmu był również obecny. W tamtym okresie tematyka ta regularnie gościła na łamach czasopism warszawskich. Redakcje starały się także przybliżyć, jak w innych krajach radzono sobie $z$ rosnąca fala alkoholizmu i ocenić, czy podobne inicjatywy miały szanse powodzenia na ziemiach polskich. $Z$ racji na to, że ruchy antyalkoholowe

\footnotetext{
65 D.K., „Liga kupujących”, Tygodnik Mód i Powieści, nr 14, 1909, 2.

66 T.M., „Ze spraw kobiecych”, Tygodnik Mód i Powieści, nr 24, 1901, 196.

67 Polish Women's Alliance of America (PWAA) - największa kobieca organizacja polonijna utworzona w 1898 r. w Chicago. Jej założycielka była emigrantka z Polski Stefania Chmielińska. Walczono o prawa kobiet na różnych płaszczyznach i spełniano różne role społeczne, by pomóc swoim społecznościom. Popierano też sprawę narodową Polski. Stowarzyszenie istnieje do dnia dzisiejszego. [Dostęp: 14.02.2019]. Dostępny w World Wide Web: <http://www.pwaa.org/about_us.html>; Andrzej Brożek, Polonia amerykańska: 1854-1939, (Warszawa : Interpress, 1977), 67-68.

68 M., „Zjazd Polek w Ameryce”, Tygodnik Mód i Powieści, nr 49, 1908, 5.
} 
były w Stanach Zjednoczonych dość silne, a kobiety odgrywały w nich czołową rolę, mogły stanowić wzór dla rodzimych inicjatyw. W „Tygodniku Mód i Powieści" o problemie walki z alkoholizmem w USA pisano niewiele, a był to ważny element aktywności kobiet na tamtym obszarze.

\section{Podsumowanie}

Aktywność Amerykanek była o wiele większa niż zaprezentowano w „Tygodniku Mód i Powieści”. Zwracano uwagę tylko na niektóre aspekty ich działalności, przedstawiając dany problem bardzo ogólnie i wybiórczo. Wiele ważnych spraw pominięto. Po wojnie secesyjnej Stany Zjednoczone przechodziły wiele przeobrażeń. Zaistniała konieczność przyznania praw wyzwolonym Murzynom. Przy tej okazji kobiety chciały usankcjonować swoje postulaty. Wiele $z$ nich było oburzonych tym, że niedawni niewolnicy otrzymali prawa polityczne, co gwarantowała im XV Poprawka do Konstytucji, a one nie. Niewątpliwie na przełomie wieków zaangażowanie kobiet w różne formy walki o prawa stale rosła. Nie wpłynęło to jednak na wzrost zainteresowania czasopisma tym problemem. Brak zainteresowania tą tematyką można również tłumaczyć tym, że w periodykach tamtego okresu, tym bardziej kobiecych, rzadko podejmowano kwestie polityczne.

W „Tygodniku Mód i Powieści” często dodawano negatywne komentarze odnośnie do walki Amerykanek o przyznanie praw. Przy tej okazji zaznaczano też, że nie należało zaszczepiać tego typu idei na gruncie polskim, ponieważ były one niemożliwe do zrealizowania ze względu na inna specyfikę regionu. Mimo wszystko czytelniczki dowiadywały się, że na innym kontynencie kobiety cieszyły się większymi swobodami, miały więcej praw i mogły realizować swoje aspiracje polityczne i zawodowe, co nie mogło umknąć ich uwadze.

\section{Bibliografia}

\section{Źródła:}

„Magazyn Mód i Nowości dotyczacych gospodarstwa domowego”, 1860-1961 „Nasz Dom”, 1913-1915

„Tygodnik Mód i Nowości Dotyczących Gospodarstwa Domowego”, 18621868 
„Tygodnik Mód i Powieści”, 1871-1911

„Tygodnik Mód i Powieści - Nasz Dom”, 1912

\section{Opracowania:}

Bokszański, Zbigniew (red.). Encyklopedia socjologii, t. 1, (Warszawa : Oficyna Naukowa, 1998). ISBN 83-85505-71-7.

Brożek, Andrzej. Polonia amerykańska: 1854-1939, (Warszawa : Interpress, 1977).

Brubaker, Jana. „Foster, Judith Ellen Horton (1840-1910)”, w: Jack S. Blocker, David M. Fahey, Ian R. Tyrrell (eds.), Alcohol and Temperance in Modern History: an International Encyclopaedia, vol. 1, (Santa Barbara : ABC-CLIO, 2003), 246-247. ISBN 1-57607-833-7

Burzyńska, Anna, Markowski, Michał Paweł. Teorie literatury XX wieku. Podręcznik, (Kraków : Znak, 2007). ISBN 978-83-240-0737-0.

Drachman, Virginia G. „Female Solidarity and Professional Success: the Dilemma of Women Doctors in Late Nineteenth-Century America", Journal of Social History, vol. 15, no. 4, 1982, 607-619. ISSN 1527-1897.

Drexlerowa, Anna M. Polska i Polacy na powszechnych wystawach światowych 1851-2001, (Warszawa : Instytut Sztuki Polskiej Akademii Nauk, 2005). ISBN 83-89101-42-4.

Dumas, Malone (ed.). Dictionary of American Biography, vol. 11, (New York : Charles Scribner's Sons, 1933).

Evans, Sara Margaret. Born for Liberty: a History of Woman in America, (New York-London : The Free Press : Collier Macmillan Publ., 1989). ISBN 0-02-902990-2.

Frank, Lisa Tendrich (ed.). Women in American Civil War, vol. 1, (Santa Barbara : ABC-CLIO, 2008). ISBN 978-1851096008.

Franke, Jerzy. Polska prasa kobieca w latach 1820-1918: $w$ kregu ofiary i poświęcenia, (Warszawa : Wydawnictwo SBP, 1999). ISBN 83-87629-29-4. Hymowitz, Carol, Weissman, Michaele. A History of Women in America, (New York : Bantam Books, 1978). ISBN 0-553-26914-3.

Jun, Hanna. Feminizm, przeł. Agnieszka Kaflińska, (Poznań : Zysk i S-ka, 2010). ISBN 978-83-7506-442-1. 
Kmiecik, Zenon. „Prasa polska w Królestwie Polskim i Imperium Rosyjskim w latach 1865-1904", w: Jerzy Łojek (red.), Prasa polska w latach 1864 1918, (Warszawa : PWN, 1976), 11-57.

Kmiecik, Zenon. Prasa warszawska w latach 1886-1904, (Wrocław : Zakład Narodowy im. Ossolińskich, 1989). ISBN 83-04-0304-3.

Kmiecik, Zenon. Prasa warszawska w okresie pozytywizmu (1864-1885), (Warszawa : PWN, 1975).

Kosteccy Izabella i Wojciech. 50 + 1. Kalejdoskop stanów Ameryki, (Warszawa : „Linia”, 1991). ISBN 83-85151-06-0.

Kuźma-Markowska, Sylwia. Zdrowe matki, chciane dzieci. Ruch kontroli urodzeń $w$ stanie Illinois (1923-1941), (Warszawa : Wydawnictwo Neriton, 2009). ISBN 978-83-7543-104-9.

Nelson, Limerick Patricia. „Amerykański Zachód: 1848-1917”, w: Walter Nugent, Halina Parafianowicz (red.), Historia Stanów Zjednoczonych Ameryki, t. 3, (Warszawa : PWN, 1995), 93-122. ISBN 83-01-11894-6.

Matthews, Jean V. Women's Struggle for Equality: the First Phase, 18281876, (Chicago : Ivan R. Dee, 1997). ISBN 1-56663-145-9.

Mauk, David, Oakland, John. Cywilizacja amerykańska, (Wrocław : Astrum, 1999). ISBN 83-7249-113-5.

Micozzi, Marc. Fundamentals of complementary and alternative medicine, (St. Louis : Saunders/Elsevier, 2011). ISBN 978-0443065767.

Mott, David C. „Judith Ellen Foster”, The Annals of Iowa, vol. 19, nr 2, 1933. ISSN 2473-9006 (online), 0003-4827 (print).

Muccigrosso, Robert. Celebrating the New World: Chicago's Columbian Exposition of 1893, (Chicago : Ivan R. Dee, 1993). ISBN 978-1-56663-014-6.

Warner, Charles Dudley (ed.). A Library of the World's Best Literature, vol. 9, (New York : Cosimo Classics, 2008). ISBN 978-1605202020.

Zaleska, Zofia. Czasopisma kobiece w Polsce (materiały do historii czasopism). Rok 1818-1937, (Warszawa : Wyższa Szkoła Dziennikarska, 1938).

\section{Publikacje internetowe:}

https://www.nymc.edu/about-nymc/history/ http://www.pwaa.org/about_us.html 